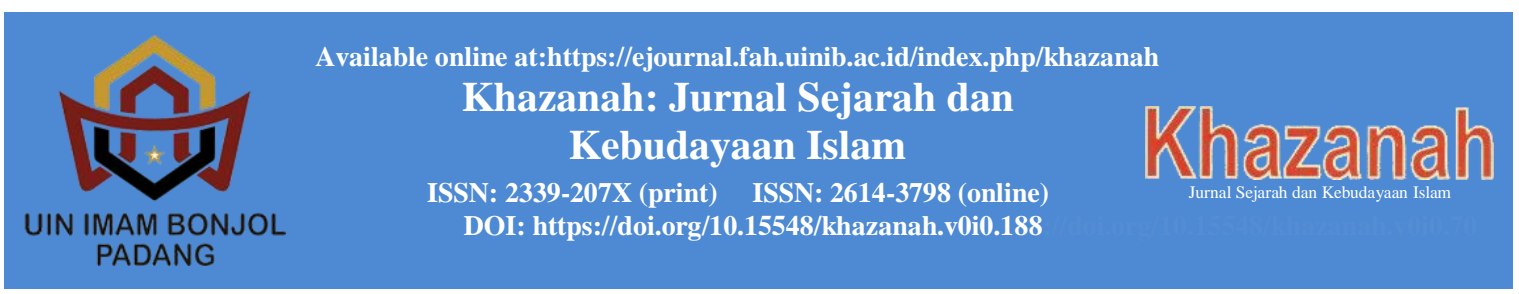

\title{
NILAI-NILAI PENDIDIKAN DALAM TRADISI BATAGAK PANGULU DI KABUPATEN LIMA PULUH KOTA
}

\author{
Lisna Sandora \\ Fakultas Adab dan Humaniora \\ UIN Imam Bonjol Padang \\ email: lisnasandora@yahoo.com
}

\begin{abstract}
Minangkabau is an area in Indonesia that has customs that have distinctive characteristics, one of the traditions carried out by the Minangkabau community is the Batagak Pangulu tradition which is held by one of the tribes in Minangkabau, especially in the Regency of Fifty Cities. Batagak pangulu is a traditional ceremony that functions to elect and appoint new tribal leaders or replace old tribal leaders. So batagak pangulu is a ceremony of changing or inheriting the leadership of a people in Minangkabau custom. As a very strong tradition in the community, the batagak pangulu procession

contains educational values in the form of educational values about leadership, deliberation, cooperation, art and politeness values, etiquette and language speech.
\end{abstract}

Keywords: Educational Values, Batagak Panghulu tradition

\begin{abstract}
Abstrak
Minangkabau adalah suatu wilayah di Indonesia yang mempunyai adat istiadat yang mempunyai ciri khas, salah satu tradisi yang dilakukan oleh masyarakat Minangkabau adalah tradisi Batagak Pangulu yang diselenggarakan oleh salah satu suku yang ada di Minangkabau khususnya di Kabupaten Lima Puluh Kota. Batagak pangulu adalah sebuah upacara adat yang berfungsi untuk memilih dan mengangkat pemimpin kaum yang baru atau mengganti pemimpin kaum yang lama. Jadi batagak pangulu merupakan upacara pergantian atau pewarisan kepemimpinan suatu kaum di dalam adat Minangkanau. Sebagai tradisi yang sangat kental dalam masyarakatnya, prosesi batagak pangulu mengandung nilai-nilai pendidikan berupa nilai pendidikan tentang kepemimpinan, musyawarah, kerjasama, seni dan nilai sopan satun, tatakrama serta tutur kata berbahasa.
\end{abstract}

Kata Kunci: Nilai-nilai Pendidikan, tradisi Batagak Panghulu 


\section{PENDAHULUAN}

Masyarakat Minangkabau telah dikenal sebagai masyarakat yang menjunjung tinggi adat-istiadatnya. Berbagai dimensi dalam kehidupan bermasyarakat selalu dikaitkan dengan adat, baik pada tataran normatif maupun dalam tataran praktis. Pada tataran normatif, adat menjadi suatu sistem, pola, dan norma yang mengatur masyarakatnya dalam kehidupan bermasyarakat. Sedangkan pada tataran praktisnya, maka pengaruh adat tampak jelas dengan diselenggarakannya berbagai bentuk festival kesenian rakyat dan upacara adat Minangkabau seperti upacara batagak pangulu.

Sebagai penganut sistem Matrilineal, masyarakat Minangkabau memandang kehadiran seorang pimpinan sangat diperlukan dan dibutuhkan, karena pemimpin dapat membimbing, mengarahkan dan mengatur anak kemanakan dalam berbagai hal. Pemimpin adat di Minangkabau terdiri dan mamak dan penghulu, mamak adalah pemimpin dalam satu kaum sedangkan penghulu merupakan pemimpin suku. Pengangkatan seorang penghulu melalui berbagai macam persyaratan dan prosesi. Batagak pangulu merupakan acara adat di Minangkabau dalam rangka mengangkat seorang penghulu. Upacara ini diselenggarakan secara besar-besaran dengan memotong kerbau dan berlangsung selama satu minggu atau 7 hari. Pengangkatan penghulu tidak bisa hanya diselenggarakan oleh kaum tersebut saja, tetapi harus dihadiri oleh orang tigo jiniah dan KAN yang ada di nagari tersebut, dan di dalam pelaksanaan peresmiannya harus berpedoman kepada petitih adat Minangkabau. Prosesi pengangkatan penghulu harus berpedoman kepada aturan adat yang sudah ada.

Pengangkatan penghulu tidak boleh dilakukan oleh sembarangan orang saja, akan tetapi kaum terlebih dahulu memilih siapa yang akan dijadikan penghulu bagi sukunya, karena penghulu ini adalah orang yang bijaksana, arif dapat mengayoni anak kemanakan dan tidak boleh memihak. Makanya para anak kemanakan harus memilih secara alua jo patuik dalam pengangkatan pengulu. Setelah disepakati bersama baru diajukan kepada anggota KAN bahwa akan diadakan pengangkatan penghulu di dalam suku tersebut. Banyak nilai-nilai pendidikan yang tertanam di dalam proses pengangkatan penghulu, terkhusus di daerah Kabupaten Lima Puluh Kota Provinsi Sumatera Barat. Sampai saat ini pengangkatan pengulu di daerah tersebut masih menggunakan teknik musyawarah dan mufakat. Semua harus didiskusikan dan tidak boleh sembarangan dan mendapatkan kesepatan dari semua kaumnya.

$$
\text { Nur Anas Zaidan }
$$

menambahkan, penghulu adalah orang yang didahulukan selangkah dan ditinggikan seranting oleh anak kemanakannya, seperti kata pepatah "diamba gadang, diampiang tinggi", maksudnya kata-katanya didengar, perintahnya diturut, selama penghulu itu masih di jalan yang benar atau berpegang kepada garis-garis adat yang telah ditentukan berdasarkan mufakat menurut alua dan patuik dalam berbuat dan bertindak. Apabila tindakannya diluar norma yang berlaku maka ia akan mendapat reaksi atau tantangan dari orang yang dipimpinnya baik secara lansung maupun secara tidak lansung. Sesuai dengan pepatah adat yang mengatakan; Raja adil raja disembah, raja lalim raja disanggah' (Nur Anas Zaidan 1982:19) (Marthala, 2014)

Menjadi seorang penghulu harus memenuhi persyaratan diantaranya calon penghulu haruslah seorang lakilaki, penghulu harus orang yang baik dan berasal dari keluarga yang baik juga, telah balig (dewasa) dan berakal, seorang penghulu harus orang yang berilmu, penghulu harus orang yang arif dan bijaksana, pengulu haruslah memiliki sifat tablig yaitu menyampaikan yang baik-baik kepada 
masyarakat dan seorang penghulu harus bersifat pemurah tulus dan sabar.

Salah satu daerah di Sumatera Barat yang menyelenggarakan pengangkatan pengulu berada di Kabupaten Lima Puluh Kota. Letak dan Kondisi geografis Kabupaten Lima Puluh Kota merupakan Kabupaten paling timur di Provinsi Sumatera Barat yang merupakan pintu gerbang utama dijalur darat dengan provinsi Riau. Secara geografis Kabupaten Lima Puluh Kota terletak pada 02528,71 LU 02214,52 LS dan 1001544,10 BT 1005047,80 BT. Kabupaten Lima Puluh Kota diapit oleh 4 Kabupaten dan 1 Provinsi yaitu Kabupaten Agam, Kabupaten Tanah Datar, Kabupaten Sijunjung dan Kabupaten Pasaman serta Provinsi Riau (antaranews.com). Nilainilai pendidikan yang dapat diambil dari proses pengangkatan penghulu beberapa diantaranya adalah nilai pendidikan seni, sopan santun, dan tata krama. Banyak nilai-nilai yang terkandung di dalam prosesi pengangkatan penghulu tersebut yang dapat diambil maknanya pada aspek pendidikan yang dapat dimaknai dari setiap prosesi yang dilakukan.

Dalam kerangka berpikir fungsional, setiap peristiwa budaya yang masih dipertahankan oleh pendukungnya diasumsikan masih menjalankan fungsi tertentu bagi masyarakat tersebut. Dalam konteks ini penelitian berikut mencoba mengungkapkan bahwa terdapat banyak nilai-nilai dalam pengangkatan seorang penghulu di daerah Minangkabau. Penghulu mempunyai arti yang sangat dalam bagi masyarakat Minangkabau. Nur Anas Zaidan mengatakan bahwa penghulu adalah orang yang didahulukan selangkah dan ditinggikan seranting oleh anak kemenakannya, seperti kata pepatah " diamba gadang, diampiang tinggi”, maksudnya katakatanya didengar, perintahnya diikuti, selama penghulu itu masih di jalan yang benar atau berpegang kepada garis-garis adat yang telah ditentukan berdasarkan mufakat menurut alua dan patuik dalam berbuat dan bertindak. Apabila tindakannya di luar norma yang berlaku, maka ia akan mendapat reaksi dan tantangan dari orang yang dipimpinnya baik secara langsung maupun secara tidak langsung. Sesuai dengan pepatah adat yang mengatakan "Raja adil raja disembah, raja lalim raja disanggah (Nur Anas Zaidan 1982;19).

Pendapat di atas didukung oleh Kamardi Rais (2000), kebesaran seorang penghulu karena ada yang membesarkannya, melalui suatu proses musyawarah kaum sehingga mencapai suatu kesepakatan semua anggota kaum yang bersangkutan. Seorang penghulu juga harus mempunyai wawasan dan dapat mengembangkan diri dalam bidang ilmu pengetahuan dan kemasyarakatan atau dengan kata lain 'tinggi disentak rueh, gadang dilintang pukam". Maksudnya adalah ibarat tingginya kayu, tinggi karena ruas menyentak (bertambah) dari hari ke hari sehingga menjadi tinggi. Pertumbuhan diri pribadinya berkembang sebagai sosok pimpinan sehingga ia akan menjadi seorang pimpinan yang berwawasan luas dan sabar sebagaimana istilah "ba alam laweh, bapadang leba" beralam luas dan berpandangan lebar) serta kharismatik.

\section{METODE PENELITIAN}

metode etnografi yang dapat menggambarkan kebudayaan secara mendalam. Penelitian ini berkenaan dengan upacara pengangkatan penghulu di daerah Minangkabau. Karena itu metode etnografi sangat cocok digunakan dalam mengambarkan prosesi nilai-nilai pendidikan dalam pengangkatan penghulu secara mendalam. Teknik pengumpulan data telah dilakukan melalui observasi, wawancara dan dokumentasi, serta studi literatur. Sedangkan teknik analisis data dilakukan dengan mereduksi data, display data dan menyimpulkan data penelitian. 


\section{PEMBAHASAN}

Minangkabau merupakan suatu daerah kebudayaan dalam wilayah administratif Sumatera Barat. Daerah ini banyak memiliki adat istiadat yang unik. Pada setiap aktivitas yang dilakukan banyak mengandung nilainilai yang dapat diambil maknanya oleh masyarakat, salah satu aspek batagak panghulu yang dapat diambil dari nilainilai pendidikan dari setiap tradisi yang dilakukan. Batagak pangulu merupakan acara tradisi pengangkatan panghulu yang dilakukan melalui prosesi yang panjang dan dilakukan secara mufakat melalui beberapa aturan yang harus dipenuhi oleh suku yang akan mengankat penghulu di dalam sukunya.

Upacara batagak pangulu dilakukan oleh masyarakat untuk mengangkat penghulu baru. Hal ini dilakukan untuk memberitahukan kepada masyarakat banyak bahwa mereka sudah memilih pemimpin suku yang baru dan disampaikan secara hormat. Pasambahan dilakukan untuk mengangkat penghulu baru karena penghulu lama sudah meninggal dunia dan diberitahukan kepada masyarakat dengan melakukan proses adat nagari pengangkatan panghulu yang dilakukan oleh masyarakat yang ada di nagari tersebut khususnya Kabupaten Lima Puluh Kota.

Dalam prosesi upacara batagak pangulu salah satunya yang terdapat pada Nagari Andaleh terkandung nilainilai Islam tentang kepemimpinan yang terserap dalam adat Minangkabau. Dengan kata lain Islam mewariskan nilai-nilai kepemimpinan ke dalam adat Minangkabau. Dalam hal ini, nilai-nilai Islam menjadi pedoman dalam memilih seorang pemimpin adat atau pangulu kaum sekaligus menuntun calon pangulu atau pangulu-pangulu lainnya dalam melakukan tugasnya memimpin kaum, anak dan kemenakan. Bibit pemimpin di dalam prosesi batagak pangulu memang menjadi poin paling penting, karena salah satu tujuan dari diadakannya upacara batagak pangulu adalah untuk mendapatkan figur yang sesuai menjadi pemimpin suatu kaum.

Menurut seorang tuo kampuang, Masri Dt. Rajo Dirajo nan Gamuak, dalam memilih pemimpin kaum, kampuang ataupun pemimpin suku, anggota kaum haruslah merujuk kepada sipoak nan ompek (sifat yang empat), yang tentu harus dimiliki seorang pemimpin yaitu shiddiq, amanah, fathonah dan tabligh. Artinya orang yang akan mereka pilih menjadi pemimpin mereka adalah orang yang memiliki sifat yang empat itu dalam diri mereka, sebagaimana sifat yang terdapat pada diri rasullullah.

Selanjutnya dalam prosesi batagak pangulu juga terdapat nilainilai tentang musyawarah. Mencermati prosesi batagak pangulu yang dilakukan mulai dari awal (rapek sapariuak) sampai akhir (upacara palewaan pangulu), terlihat tahapan yang dilakukan itu tidak terlepas dari konsep musyawarah atau pengambilan keputusan melalui mufakat. Dalam istilah adatnya dikenal sebagai sakato kaum ( Masri Dt. Rajo Dirajo nan Gamuak). Satu hal yang unik teramati di sini, untuk mendapatkan sakato kaum dalam memilih calon pangulu atau siapa yang akan dijadikan pangulu suatu kaum, tidak pernah ada namanya pemilihan dengan sistem pemungutan suara. Dalam rapat kaum yang dilakukan, niniak mamak dan seluruh kaum hadir, duduk bersama membicarakan calon pangulu yang angkat diangkat, dipandang baik buruknya, ditelaah budi dan sikapnya atau dalam istilah adatnya bapaiyo bapatidokan, kemudian diperoleh satu hasil keputusan bersama "satu kata" saja dari seluruh kaum bahwa mereka menyetujui calon yang mereka pilih. Dalam istilah adat diisitilahkan dengan kata ciek indak nan rumpang (tidak ada satupun anggota kaum yang tidak setuju dengan calon yang dipilih). Selanjutnya dari prosesi batagak pangulu, sakato kaum dikembangkan menjadi sakato 
kampuang (dalam rapek kampuang), sakato suku (dalam rapek sasuku), dan sakato nagori (rapek dalam nagori). Apa yang sudah menjadi kesepakatan kaum dalam rapek sapariuak, kemudian dibawa kedalam rapat-rapat selanjutnya untuk diambil kata mufakat atau persetujuan bersama mamacik arek mangganggam taguah, seiya sekata menyetujui seseorang tadi untuk menjadi pangulu suatu kaum.

Selain nilai-nilai kepemimpinan dan musyawarah, di dalam prosesi pengangkatan penghulu juga terdapat nilai-nilai kerjasama. Nilai-nilai ini dominan terlihat dalam dua prosesinya yaitu rapek tanjuang dan upacara pelantikan pangulu/pati ambalau. Rapek tanjuan bertujuan untuk membicarakan persiapan alek (perhelatan) akbar pelantikan penghulu, sedangkan pati ambalau adalah moment pelantikan pangulu itu sendiri.

Pelaksanaan rapek tanjuang pada hakikatnya menggambarkan bahwa masyarakat Minangkabau dalam kehidupan sehari-hari selalu menjunjung tinggi rasa kebersamaan dengan berpedoman kepada aturan, norma dan nilai yang berlaku, suka hidup bergotong royong, saling hormat menghormati, harga menghargai satu sama lain dan menjunjung tinggi nilai kebersamaan. Masyarakat bersama membicarakan persiapan alek dan saling berbagi tugas demi lancarnya alek. Setiap orang memainkan perannya masing-masing sesuai dengan ungkapan falsafah adat yang mereka anut; nan buto pahambuih lasuang, nan binguang kadisuruah-suruah dan nan cadiak lawan barundiang, artinya setiap orang sebagaimana kondisinya dapat menjalankan tugasnya sebagai bentuk partisipasinya dalam kebersamaan, dan begitu pula adanya dalam pelaksanaan upacara pelantikan penghulu pati ambalau.

Nilai pendidikan lainnya yang terdapat pada prosesi batagak pangulu adalah nilai pendidikan seni. Nilai pendidikan seni ini terlihat dari prosesi pengangkatan penghulu yang dimulai dari acara mufakat penghulu, yang dilakukan sebelum acara dimulai. Pada saat pelaksanaan pengangkatan pengulu dimulai dari tarian-tarian tradisional seperti tari pasambahan. Dalam tarian tersebut muncul nilai pendidikan berupa rasa hormat sebagaimana penari melakukan penghormatan kepada tamu yang diundang dengan cara memberikan sirih dalam carano sebagai lambang penghormatan itu sendiri, yang diberikan oleh anak daro sebagai bentuk dimulainya acara. Nilai pendidikan yang lainnya sopan dan santun yang di perlihatkan kepada semua tamu undangan yang ada. Tamu yang datang dihormati dan dihargai, tutur bahasa yang santun yang terlihat dara tibo nampak muko dan pulang tampak punguang dan nilai pendidikan melambangkan nilai ramah tamah berbudaya yang tertanam di dalam budaya Minangkabau itu sendiri.

Masyarakat Minangkabau sudah banyak yang tidak peduli dan tidak tahu lagi dengan pepatah-petitih, pantun, dan masalah-masalah adat Minangkabau. Dalam hal Batagak Gala Pangulu misalnya, tidak semua orang terampil dalam menyampaikan pidato adat, hanya orang-orang tertentu saja yang sanggup melakukannya. Hal ini disebabkan oleh kedudukan seseorang dalam adat atau karena perhatiannya yang sangat besar untuk dapat menguasai pidato adat sehingga dia akan berperan dalam kedudukannya. Pidato adat itu merupakan bagian penting dari upacara adat Batagak Gala Penghulu (Samudro, 2012).

Adanya tradisi pasambahan atau bapidato mengangdung nilai-nilai pendidikan berbahasa dan kesantunan yang dipandang sebagai orang yang berpendidikan. Pidato adat memiliki banyak manfaat dalam kehidupan bermasyarakat disamping sebagai sarana untuk mencapai kata mufakat, cara menghormati orang yang lebih tua, serta cara berbicara. Hal itu dapat terlihat dari tata cara pelaksanaan pidato 
adat dalam tradisi Batagak gala, pertama seseorang yang menyampaikan pidato adat menyatakan kalimat sapaan terlebih dahulu kepada semua orang yang hadir, agar semua orang yang hadir merasa dihormati atas kehadirannya. Saat ini pidato adat di Kenagarian Lundar walaupun sudah jarang sekali ditemukan, namun sebagian kecil masih berkembang, dengan bukti masih ada masyarakat yang mengenal pidato adat, bahkan orang yang mampu bertutur adat itupun masih ada sampai saat ini. Tradisi pidato adat dalam upacara Batagak gala dilaksanakan mulai dari hari Batagak gadang yang dihadiri oleh urang nan ampek jinih, hari perjamuan yang dimeriahkan oleh kesenian dan jamuan makan kepada semua orang yang hadir, hari perarakan yang diirigi bunyibunyian diarak ke rumah soko barulah penghulu baru itu dinobatkan (Rohman, 2017).

Dalam upacara batagak pangulu, penggunaan sastra lisan seperti petatah-petitih, falsafah adat, pantun adat, bidal, mamang dan sebagainya adalah sesuatu yang tidak bisa ditinggalkan. Semua hal ini digunakan oleh ninik mamak dalam persembahannya untuk menasehati calon penghulu kaum, dalam baiyo batido pada serangkaian rapat yang dilakukan. Palewaan pangulu ini dilakukan di alam terbuka atau dalam istilahnya medan nan bapaneh.

Pepatah dan petitih dalam adat Minangkabau yang dilakukan dalam prosesi dan kata-kata yang dikeluarkan enak didengar. Setiap pepatah yang disampaikan mengandung makna tentang proses pengangkatan penghulu, pidato yang disampaikan tidak saling balas berbalas yang disampaikan pada penobatan seorang penghulu dalam suatu di wilayah kabupaten Lima Puluh Kota (Denafri, 2018). Sopan dan santun masuk kedalam kategori kesantunan berbahasa yang terwujud pada prinsip sopan santun dalam berbahasa. Sopan santun dalam berbahasa adalah sikap yang wajib dimiliki oleh penutur suatu bahasa. Bahasa yang sopan disampaikan di dalam pidato dapat membangun hubungan baik antara penutur kata dengan lawan berbicara, di dalam bertutur kata yang disampaikan dengan baik dapat diucapkan dan dapat diterima secara santun jika disampaikan sesuai dengan ketentuan bahasa yang ada di dalam daerah tersebut. Pada akhirnya, hubungan baik antara penutur dan lawan tutur akan berdampak pada terciptanya komunikasi yang efektif (Jendri, 2019). Dalam pasambahan diajarkan nilai-nilai kesopansantunan berbahasa. Setiap orang yang melakukan percakapan harus menghormati dan dapat menghagai pendapat orang lain, apabila terjadi perdebatan di dalam pasambahan harus diselesaikan dengan baik dan dapat diterima oleh kedua belah pihak yang melakukan komunikasi sehingga lawan komunikasi tidak merasa diremehkan, orang Minang menyelesaikan perselihan atau perdebatan dengan bahasa kiasan yang dapat diterima oleh lawan bicaranya" (Denafri, 2018). Berbahasa adalah aktivitas sosial. Seperti halnya aktivitas-aktivitas sosial yang lain, kegiatan berbahasa baru terwujud apabila manusia terlibat didalamnya. Di dalam berbicara, penutur dan mitra sama-sama menyadari bahwa ada kaidah-kaidah yang mengatur tindakannya, penggunaan bahasanya, dan interpretasi-interpretasinya terhadap tindakan dan ucapan mitra. Setiap peserta tindak tutur bertanggung jawab terhadap tindakan dan penyimpangan terhadap kaidah kebahasaan di dalam interaksi lingual itu (Allan dalamWijana, 1996:45). Minangkabau (Imelda, 2011).

Banyak makna nilai-nilai pendidikan yang terkandung dalam pengangkatan penghulu selain nilai seni dan sopan dan santun masih banyak nilai-nilai pendidikan yang terkandung didalamnya seperti nilai kebersamaa, nilai sosial dan nilai 
tolerasi yang mempunyai arti dan makna dari setiap kegiatan yang dilakukan oleh masyarakat yang ada dinagari mempunyai makna yang selalu dipertahankan Minangkabau wilayah dengan nilai-nilai budaya yang banyak sehingga adat tidak lakang dek paneh dan tidak lapuak dek hujan. Semua prosesi adat dan istiadat masih tetap dipertahankan sampai saat ini.

\section{KESIMPULAN}

Semua tradisi yang dilakukan oleh Masyarakat Minangkabau dilakukan secara turun temurun dan selalu disosialisasikan oleh ninik mamak dan para pemangku adatnya. Sejarah masuknya Islam ke Minangkabau ditenggarai membawa pengaruh yang cukup luar biasa terhadap nilai-nilai dan ajaran adat Minangkabau, dimana nilai dan ajaran adat tersebut dipengaruhi oleh nilai-nilai dan ajaran Islam. Proses integrasi nilainilai Islam dengan nilai-nilai adat diyakini melahirkan rumusan yang mantap dan melahirkan filosofi "Adat basandi syara' dan syara' basandi kitabullah, syra' mangato adat mamakai. Pengakatan penghulu di Minangkabau dilakukan dengan prosesi yang tidak lari dari ketentuan dan aturan-aturan yang telah ditetapkan oleh Moyang terdahulu.

Banyak nilai-nilai pendidikan yang terdapat di dalam upacara Pengangkatan Panghulu di Kabupaten Lima Puluh Kota seperti nilai-nilai kepemimpinan, musyawarah, kerjasama, sopan santun berbahasa dan seni. Setiap nilai yang terdapat dalam prosesi tersebut saling bersinergi dan melambangkan kondisi masyarakatnya. 


\section{DAFTAR PUSTAKA}

Denafri, B. (2018). Kesopanan Berbahasa dalam Teks Pasambahan Tinjauan Pragmatik. Jurnal KATA, 2(2), 336-346.

Hakimy, I. (1984). Pokok-pokok Pengetahuan Adat Alam Minangkabau. Bandung:Remaja Rosdakarya

\section{(1994). Pengangkatan penghulu, Bundo kandung dan Pidato Alua Pasambahan Adat di Minangkabau. Bandung:Remaja Rosdakarya}

Imelda. (2011). Implikatur Pasambahan dalam Batagak Gala di Kanagarian Pauh V. In Universitas Andalas.

http://ridum.umanizales.edu.co:8080/jsp ui/bitstream/6789/377/4/Mu $>\mathrm{oz}_{\text {_ }}$ Zapata_Adriana_Patricia_Artculo_ 2011.pdf

Jendri. (2019). Realisasi Kesantunan Berbahaasa di Lingkungan Sekolah Dasar Kota Padang. Angewandte Chemie International Edition, 6(11), 951-952., 3(23), 32-41.

Kamardi Rais Dt. P.Simulie (2000). Kepemimpinan Ninik Mamak di Minangkabau. Disampakan pada Penataran Budaya Alam Minangkabau, Solok Sumatera Barat bulan Mei

Marthala, A. E. (2014). Penghulu dan Filosofi Pakaian Kebesaran Konsep Kepemimpinan Tradisional Minangkabau.

Rohman, A. (2017). Struktur dan Fungsi Pidato Adat dalam Tradisi Batagak Gala di Nagari Lundar Kecamatan Panti Timur Kabupaten Pasaman. In Stekip PGRI Sumbar (Vol. 87, Issue 1,2).
Samudro, R. (2012). Nilai-Nilai Budaya Minangkabau dalam Teks Pidato Batagak Gala Penghulu Karya Idrus Hakimi Datuak Rajo Penghulu (Issue September). Universitas Negeri Padang. 